Bryant University

Bryant Digital Repository

$2-2011$

\title{
Connection, Trust, and Commitment: Dimensions of Co-creation?
}

\author{
Wesley S. Randall \\ Auburn University \\ Michael Gravier \\ Bryant University \\ Victor R. Prybutok \\ University of North Texas
}

Follow this and additional works at: https://digitalcommons.bryant.edu/mark_jou

\section{Recommended Citation}

Randall, Wesley S.; Gravier, Michael; and Prybutok, Victor R., "Connection, Trust, and

Commitment: Dimensions of Co-creation?" (2011). Marketing Department Journal Articles.

Paper 27.

https://digitalcommons.bryant.edu/mark_jou/27

This Article is brought to you for free and open access by the Marketing Faculty Publications and Research at Bryant Digital Repository. It has been accepted for inclusion in Marketing Department Journal Articles by an authorized administrator of Bryant Digital Repository. For more information, please contact dcommons@bryant.edu. 


\title{
Connection, Trust, and Commitment: Dimensions of Co-Creation?
}

\author{
W. S. Randall \\ Department of Aviation and Supply Chain Management, College of Business, Auburn \\ University, USA
}

Michael J. Gravier

Department of Marketing, College of Business, Bryant University, USA

\section{Victor R. Prybutok}

Regents Professor of Decision Sciences, Director of the Center for Quality and Productivity, and Fellow in the Texas Center for Digital Knowledge at the University of North Texas, ITDS Deptartment, College of Business Administration, USA

Dr. Wesley Randall, Department of Aviation and Supply Chain Management, College of Business, Auburn University, 215 West Magnolia, Lowder Business Building Suite 435, Auburn, AL 36849-5350 USA (e-mail: wsr0001@ auburn.edu; phone: (334) 728-4920; fax: (334) 369-7012). Dr. Michael J. Gravier, Department of Marketing, College of Business, Bryant University, 1150 Douglas Pike, Smithfield, RI 02917-1284 USA (e-mail: mgravier@bryant.edu; phone: (401) 232-6950; fax (401) 232-6319). Dr. Victor R. Prybutok, University of North Texas, ITDS Dept., College of Business Administration, PO Box 305249, Denton, TX 76203-5249 USA (e-mail: prybutok@unt.edu; phone: (940) 565 - 4767, fax: (940) 565 - 4935).

(Received 31 July 2009; final version received XXX)

The purpose of this research is to identify a key driver of relationship closeness for service organizations. Based upon the co-creation concept from Service-Dominant Logic, connection is proposed as a new construct rooted in emotional attachment that bolsters the effect of trust and commitment on future intention among customers of a service-intense organization. Causal models are verified with a large empirical sample drawn from an organization in the process of dealing with the increasing sense of depersonalization that has afflicted growing organizations in a variety of industries. The paper distinguishes an important dimension of customer relationships that can be affected by service managers in order to enhance customer loyalty and satisfaction.

Keywords: Relationship management, customer satisfaction, services management, satisfaction, service quality, customer relationship management 


\section{Introduction}

Recent research has demonstrated that the greater customization of service offerings versus traditional mass produced goods means that closer relationships are required to bolster the value offerings of services firms (Johnson et al., 2004). Practitioners can passively or actively pursue close customer relationships. A passive approach relies on segmenting customers based upon relational or transactional outlook; seminal research into such segmentation appears in the research of Garbarino and Johnson (1999) that showed that customers vary in their orientation toward a service-providing firm and recommended segmenting customers. The passive approach appears in customer portfolio research both in industrial (Fiocca, 1982; Rangan et al., 1992) and consumer markets (c.f., Verhoef, 2003) as a means of identifying higher value customers with little regard for actively changing relationship closeness. An active approach to creating closer customer relationships means of increasing both value content and satisfaction by involving the customer in the service creation process (Vargo and Lusch, 2004). An active approach seems more desirable since it means proactively managing business relationships. However, a review of the recent seminal work in customer relationship research highlights an important problem: research has yet to identify the underlying mechanism or "switch" that will turn transactional customers into relational customers.

Recent conceptual research that suggests that switch may be sense of connection that is fostered by both customer-customer and customer-firm engagement in a process Vargo and Lusch (2004) call co-creation. Further scholarship reveals that co-creation and a sense of connection likely constitute part of a "mega-construct" consisting primarily of trust, commitment, and satisfaction as indicators of the degree to which an exchange relationship moderates customer sense of value (Moliner et al., 2007). Understanding of how trust and 
commitment interact, and the causes of trust and commitment, has remained elusive-indeed, finding those causes has been called "a research question of great urgency (Garbarino and Johnson, 1999, p. 82)." However, the co-creation mechanism, how co-creation might be tested, and what might be the dimensions of co-creation represent gaps in this new area of research.

To address that gap we conducted a robust research program that includes qualitative and quantitative methods to measure connection and create a structural equation model aimed at theory exploration. In conducting this work we rely on the idea of co-creation outlined in the framework of Service-Dominant (S-D) Logic. S-D Logic provides an explanation for the highly relational, knowledge-based value propositions that characterize modern exchange (Vargo and Lusch, 2004). A central premise of S-D Logic posits that satisfaction, value, and repeat patronage are likely to increase when the producer and the customer co-create the service offering (Lusch and Vargo, 2006). By increasing customer involvement in the production process, customers and services providers generate greater knowledge of each other which leads to a more relational orientation and higher sense of value.

The overall purpose of this research is to test whether and to what extent does a sense of connection rooted in emotional attachment bolster the effect of trust and commitment on future intention among customers of a service-intense organization. In the course of meeting this objective, this research effort developed a new connection construct grounded in cocreation aspect of the S-D Logic paradigm that sheds light on the consumer's perspective on relationship management and the business's ability to influence the consumer's decision. The rest of the paper is organized as follows. First, we present the literature review on co-creation and related literature dealing with satisfaction, trust, commitment and future intention. Then exploratory field research is presented that discovers the connection construct. In order to verify the connection construct's relation to other dimensions, a sample of 1,650 is used to 
create multiple competing models to determine, in an exploratory fashion, how sense of connection performs in comparison to, and in conjunction with, relational constructs in a model used to predict future intention. Based upon comparisons to extant models of relational exchange, the possible different influences of connectedness are assessed. A model is tentatively proposed for further future corroboration before this manuscript concludes with implications for research and practitioners as well as limitations and recommendations for future research.

\section{Literature Review}

\section{Theoretical Insights: Co-Creation}

The traditional goods-centered perspective of marketing views the customer as the target of production and marketing (Vargo and Lusch, 2004; Kohli and Jaworski, 1990; Levitt, 1960; Narver and Slater, 1990). In the traditional view the production process adds value to a product, and then marketing captures the value through an exchange process via the price. SD Logic framework expands the explanatory power of the traditional view by positioning a customer's value determination in two additional dimensions beyond price (Vargo and Lusch, 2004). First, customers realize the value of a service offering as they consume the service or the good. The performance of the service or product thus influences customer valuation of utility, creating "value-in-use." Second, customers often participate in the production of the good or service. "Co-production" can occur via customization, co-innovation, or direct coparticipation of the customer in the production process. The value proposition offered by the organization therefore is contextual and dependent upon co-production with the customer(s). Depending on the context the same product or service takes on different value for the customer(s). While the product itself may remain constant, the value proposition does not; the customer's desires and experiences evolve in response to time, place, and company (Prahalad 
et al., 2004). As the context changes so does the worth of the co-created value proposition.

This literature review elaborates on four dimensions of co-creation as: 1) an evolutionary and communal process, 2) possibly subsuming trust and commitment, 3) influencing satisfaction, and 4) influencing future intention.

Co-creation is an evolutionary process that occurs not only between the firm and the customer but also among the community of customers

From a service-dominant view, value creation is no longer the end result of a dyadic exchange between a seller and a customer at a fixed point in time as determined by the price (Vargo and Lusch, 2004; Chen and Watanabe, 2007; Payne et al., 2008; Prahalad, 2004). Instead value occurs throughout the interactive co-creation process between a customer and a firm (Chen and Watanabe, 2007). Furthermore, the firm and the customer are each embedded in a network of other firms and customers. As Prahalad and Ramaswamy (2004, p. 8) state, the "firm-centric view of the world, refined over the last 75 years, is being challenged not by new competitors, but by communities of connected, informed, empowered, and active consumers." Value is continuously re-inventing itself based upon the interactions of individuals and organizations, leading the co-creation process to evolve over time (c.f., Reinartz and Kumar, 2000).

Co-creation inherently implies, and possibly subsumes, trust and commitment Jaworski \& Kohli (2006, p. 117) proposed that the co-creation process nurtures commitment based on the rationale that, "because a customer is involved in the process, the customer builds commitment to the resultant offering by the firm." Trust is built through the equality inherent in dialogue. Through dialogue, the customers and the firm, as well as the community of customers amongst themselves, create bonds of integrity and shared risk. The act of cocreation requires firms to embrace transparency, good and bad, associated with their products. As a result, trust in this dialogue is increased through co-creation. 
Co-creation influences satisfaction

Fournier and Mick (1999) argued for a holistic contingency view of satisfaction that incorporates the relational dimensions. An increased relational content implies increased cocreation. The co-created offering is inherently customized as contextual aspects of the exchange become tailored to each customer. Jaworski and Kohli (2006) find that "because the offering is co-developed, it has a higher probability of accurately meeting the customer needs." Therefore, an increase in co-created offerings should increase satisfaction for relational customers. Non-relational (transactional) customers perceive low value in return for their commitment to the exchange; for these customers an increase in co-created offerings should decrease satisfaction.

\section{Co-creation influences future intention}

Co-creation implies a convergence in the roles of the customer and the firm (Prahalad and Ramaswamy, 2004). The co-creating customer becomes part of the process of value creation, an inextricable part of future value creation within the network (Payne et al., 2008; Jaworski and Kohli, 2006; Liang and Wang, 2008). The process of co-creation increases the likelihood of positive future intention because the firm generates unique insights into the co-creating customers' sources of value. The understanding of customer sources of value, and how that value evolves, inoculates the firm against competitive offerings (Payne et al., 2008; Jaworski and Kohli, 2006; Liang and Wang, 2008). This inoculation process means that co-creation "represents a source of significant competitive advantage (Jaworski and Kohli, 2006, p. 116)" due to increased customer satisfaction and positive impact on future intention.

\section{Trust, Commitment, Satisfaction, and Future Intention}

The abovementioned literature suggests that co-creation may add a dimension to trust and commitment that better explains the firm-customer connection (Prahalad and Ramaswamy, 2004; Prahalad, 2004; Zeithaml et al., 1996). Scholars have little explored how co-creation 
and connection lead to future intention, and how these constructs influence customer relationship management. Past efforts have identified several constructs that provide insights into the co-creation process such as satisfaction and future intention as well trust and commitment (Garbarino and Johnson, 1999; Morgan and Hunt, 1994; Zeithaml et al., 1996; Palmatier et al. 2006, Gruen et al. 2000; Tax and Brown, 1998). More recent research has attempted to link trust, commitment, and future intention (Vargo and Lusch, 2004; Prahalad and Ramaswamy, 2004; Jaworski and Kohli, 2006). Salient features of these constructs follow.

Trust

Morgan and Hunt (1994) conceptualize trust as a state that exists when one party has confidence in an exchange partner's reliability and integrity. Trust relates to the customer's confidence that the organization will reliably provide satisfactory service in a manner that is competent, honest, fair, responsible, helpful and benevolent. Studies demonstrate trust as a precursor to relational commitment (Morgan and Hunt, 1994). Some studies show trust as an independent construct separate from commitment; others posit that trust is multi-dimensional (Liang and Wang, 2008; Palmatier et al., 2006; Sirdeshmukh et al., 2002). With respect to predicting future intention and satisfaction, trust alone gives inconsistent performance (Palmatier et al., 2006). Instead trust is traditionally modeled with commitment in order to render stable results (e.g., Garbarino and Johnson, 1999, Morgan and Hunt, 1994; Palmatier et al., 2006), suggesting that trust is more accurately viewed as part of a higher order, multidimensional construct.

\section{Commitment}

Morgan and Hunt (1994) define relational commitment as existing when an exchange partner believes that an ongoing relationship with another is sufficiently important to warrant maximum efforts at maintaining the relationship. Commitment captures pride in belonging, 
concern for long-term success, and a desire for customers to participate as friends of the organization (Morgan and Hunt, 1994). This conceptualization follows that of Moorman et al. (1992) who contend that commitment infers an enduring desire and willingness to work at maintaining the relationship. Commitment can be the result of emotional attachment or cognitive calculation (Geyskens et al., 1996; Wetzels et al., 1998). In the case of the individual consumer selecting among a variety of service-providers, the assumption in this paper is that emotional or affective commitment underlies loyalty decisions since commitment founded upon cognitive calculation leaves consumers prone to defection due to competitive forces and the ease of imitating service-based processes. As with trust, follow-on investigations have found conflicting results when using the classic conceptualization of commitment (Palmatier et al., 2006). Furthermore, recent meta-analytical analysis results suggest that trust and commitment are only part of that construct (Palmatier et al., 2006). Gruen, et al. (2000), argue that commitment is multi-dimensional, again suggesting that commitment, like trust, forms part of a multi-dimensional 'relational' construct.

\section{Satisfaction}

Satisfaction has dominated consumer research with respect to predicting consumer behavior over the past two decades (Zeithaml et al., 1996; Anderson et al., 1994; Cronin and Taylor, 1992; Parasuraman et al., 1994a; Szymanski and Henard, 2001). Fornell (1992) argues that satisfaction is an overall post-purchase evaluation. Anderson, Fornell, and Lehmann (1994, p. 54) consider satisfaction "an overall evaluation based on the total purchase and consumption experience with a good or service over time." Cronin and Taylor $(1992 ; 1994)$ argue that satisfaction is best measured as a single dimension reflecting attitudinal aspects.

In their landmark study of a repertory theatre company, Garbarino and Johnson (1999) found that a source of satisfaction for relational customers was the feeling of knowing the service providers (actors). Furthermore, their research revealed that relational and 
transactional customers experienced satisfaction, trust, and commitment in distinct manners. For relational customers, the effect of satisfaction with the component satisfaction-meaning individual service components (such as attitude toward the actors or the play)—on future intentions was mediated by trust and commitment. For transactional customers, future intention was influenced largely by satisfaction with the discrete transaction while trust and commitment exerted little influence.

\section{Future Intention}

Zeithaml et al. (1996) propose that customers provide detectable signals that indicate behavioral intention. They posit a link between service quality and behavioral intention, and they demonstrate that this link influences whether customers remain or defect, stressing the financial consequences of defection. Generally, studies show that trust, commitment, and component satisfaction are related to future intention (Garbarino and Johnson, 1999; Zeithaml et al., 1996; Seiders et al., 2005; Ulaga and Eggert, 2006). These studies suggest that as organizations develop a relationship they also develop the sensory apparatus required for monitoring customer behavioral trends. The development of the ability to predict behavioral intention confers a powerful form of competitive advantage.

\section{Connection as a New Construct}

The concept of a sense of connection between the customer and the service-providing organization appears commonly in the literature. Morgan and Hunt (1994) explored the efficiency of mutual benefit during the course of evolution of relational exchange, beginning with repeat purchase, maturing through relational exchange, and subsequently resulting in brand loyalty based upon positive attitudes formed over time. Westbrook (1981) showed that familiarity, intimacy, and life connection provide important emotional aspects of the exchange experience. Fournier \& Mick (1999) proposed that consumer product satisfaction is 
an active and dynamic process, based upon strong social dimension, and that this process is context dependent. Fournier \& Mick argued for a holistic contingency view of satisfaction that incorporated the relational dimensions (Fournier and Mick, 1999). Czepiel (1990) espoused the need for a development of measures for evaluation of relationship quality and strength. Garbarino and Johnson (1999) did not directly test for connection, but their construct suggested elements of familiarity, volunteerism, and monetary contribution. Garbarino and Johnson (1999) demonstrated that a sense of familiarity influenced the sense of satisfaction with the service.

Consistent with this prior research, we propose the existence of a connection construct as a necessary component for evaluating relational exchange. The connection construct measures the degree of relational connectedness as the emotional attachment with both the service organization as well as with fellow customers of that organization. Empirical evidence and instrument development for this new construct are presented subsequently.

\section{Method, Data, and Models}

Empirical research proceeded in two stages. First, qualitative research was conducted to assess the existence and dimensions of connection as a new construct. The goal of the qualitative research was to develop a scale for measuring connection. The second stage of the research was the collection of a sufficient empirical sample to conduct quantitative analysis of the role of connection relative to other established co-creation constructs.

\section{Sample}

Our field research studied a large church in the Southwestern United States. This church had more than 3000 active members spread across three locations. The organization had grown tremendously in the previous 3.5 years and had recently been named one of the fastest growing churches in 2004 and 2005 (Easum, 2005, 2006). Of particular interest to the study 
of co-creation, the organization's leaders had conducted their own informal survey with results from 432 respondents addressing both open-ended and multiple-choice questions that had convinced them that member involvement — which they called a "sense of connection"was a key aspect of their success. The senior leadership created numerous venues for members to co-create the service offering. At any given time, there were approximately 300 volunteers supporting weekly events and the many community programs.

\section{Qualitative Research and Scale Development for Connection Construct}

The techniques for field interview (Eisenhardt, 1989, 1991) and instrument development (Dillman, 2000) were used in accordance with established protocols. Five different on-site field interviews were conducted with various members of the staff, organizational members, and frequent guests. These interviews identified four spheres of connection and co-creation with customers: 1) the pastor and staff, 2) the people in the ministry area where customers volunteer, 3) feeling of familiarity with the people who attend the church, and 4) connection with the volunteer staff.

The insight gained in the field interviews and from the organization's early survey dealt with the concept that the sense of connection was most effectively captured through a personal sense of connection. Senior leadership, customers, and staff repeatedly used the term "connection," which was described as an affinity between the organization and the customers, and also between the customers themselves. This term, and its use, appeared conceptually similar to literature discussions of co-creation. Discussion with staff and members determined that manifestations of the word "connection" different from the context of co-creation did not make sense. Additionally, the participants felt relationship had a different connotation then connection. 
The organization's staff and customers identified connection as a real construct that existed in varying degrees. The following comments support this contention: "I feel very connected with..." and "I feel less connected to..." Some customers felt "less connected" as the organization grew. Other customers perceived connectedness as multifaceted; some felt connection with staff, others with the musicians, and others with fellow customers or volunteers. Both staff and customers routinely articulated a desire for a sense of connection and this desire for connection drove them to participate in numerous organizational activities. Staff and customers appeared to place value on sense of connection. The senior pastor felt that the organization would not continue to grow and meet the needs of the customers unless the sense of connection (or co-creation) could be maintained in the face of the organization's rapid growth.

\section{Development and Testing of Pilot Instrument}

Based upon the field research and past published research, a pilot survey instrument was developed. Included in the pilot study were scales used in this research were adapted from published literature that assessed satisfaction (Garbarino and Johnson, 1999; Gustafsson et al., 2005; Landrum and Prybutok, 2004; Oliver, 2006), trust and commitment (Morgan and Hunt, 1994; Palmatier et al., 2006), and behavioral intention (Garbarino and Johnson, 1999; Zeithaml et al., 1996; Cronin and Taylor, 1992; Parasuraman et al., 1994a, 1994b). Appropriate scales for connection were not available in the literature, requiring development of a new scale.

To increase content validity, marketing faculty and doctoral students from the marketing department at a large university in the Southwestern United States reviewed the questionnaire. The original instrument contained questions measuring the constructs of satisfaction, connection, trust, commitment, behavioral intention, and several demographic 
variables. The marketing faculty assessed the instrument's readability and understandability. The pilot survey items were evaluated by the focal organization's leadership for clarity and appropriateness.

A pilot survey was conducted at the church that yielded 185 usable responses.

Evaluation of the results led to clarification of a number of items. The constructs dealing with connection performed very well, exhibiting a Cronbach's alpha greater than .9 and factor loadings using principal component and Varimax rotation of greater than .8 (Dillman, 2000; Kohli et al., 1993). These results were evaluated by the academic experts and managerial experts. Based upon the positive evaluation and feedback from these groups, we refined the instrument (Garbarino and Johnson, 1999; Croning and Taylor, 1992).

\section{Development of Structural Equations Models}

The seminal work of Garbarino and Johnson (1999) demonstrated how participants who experienced the same service (attended the same play) manifested different consumption experiences based upon their relationships, or their sense of connection. This investigation begins by assessing a new sample using the widely-cited Garbarino and Johnson (1999) model, as shown in Figure 1. This re-creation is presented to establish a baseline for model performance, and to identify and qualify the sample as highly relational. Next, three competing structural equations models assess alternative structural relationships between trust, commitment, connection, and future intention. The goal is to evaluate the performance of sense of connection by competing models using various pairings between trust, commitment and sense of connection. The competing models are as follows:

- Model 1: Baseline model of trust, commitment, and future intention (Figure 2).

- Model 2: Commitment, connection, and future intention (Figure 3).

- Model 3: Trust, connection, and future intention (Figure 4).

- Model 4: Trust, commitment, connection, and future intention (Figure 5). 
The first hypothesis is that connection in a highly relational setting shares similar explanatory potential as trust and commitment with regard to future intention. Model 1

(Figure 2) predicts future intention using trust and commitment alone. Model 1 provides the basis for comparing the fit of Models 2, 3, and 4. The goal of the investigation is to determine if connection performs similarly, yet not identically, to trust and commitment. Demonstrating a differential role for connection would suggest that trust, commitment, and connection comprise the dimensions of a higher order co-creation construct. If this is the case then the following hypotheses should be empirically supported:

- Hypothesis 1: A model using trust, connection and future intention (Model 2) will share similar fit to a rival model using trust, commitment, and future intention (Model 1).

- Hypothesis 2: A model using commitment, connection and future intention (Model 3) will share similar fit to a rival model using trust, commitment, and future intention (Model 1).

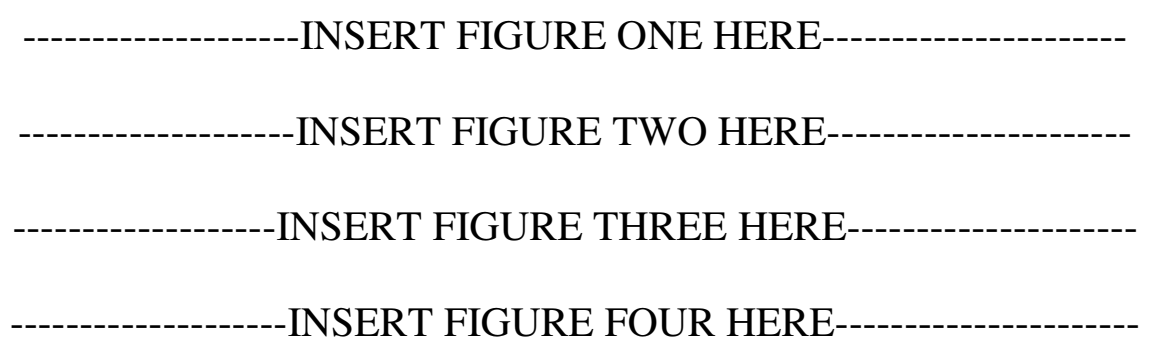

The third hypothesis posits that a model that uses connection, trust, and commitment to predict future intention generates better fit than a model using only trust and commitment to predict future intention. This hypothesis determines whether trust, commitment, and connection form an effective yet parsimonious path for predicting future intention, with connection influencing future intention both directly and indirectly through its influence on commitment.

- Hypothesis 3: A model using trust, commitment, connection, and future intention (Model 4) will share similar fit to a rival model using trust, commitment, and future intention (Model 1). 


\section{Final Instrument Deployment}

The data for the study was collected by handing out surveys to members and guests at all services during a single day (Dillman, 2000). This covered four services, two at the main campus, and two at satellite campuses. A total of 1,650 questionnaires were distributed during the Sunday service; 1,064 were passed to the ends of aisles for collection. Of those returned, 31 were returned blank, and 12 were filled out by individuals younger than 18 . Due to concerns over the time limitation doing a survey during the service, the decision had been made ahead of time to exclude surveys that were not filled out $100 \%$ on the constructs of interest, which resulted in the exclusion of 436 surveys that were turned in blank or were only just started. In total, 479 were rejected, leaving a usable sample of 585 surveys, or about $55 \%$ of the returned sample. Of those surveys returned incomplete, a review of the demographics dealing with length of attendance, member/non-member, age, income, and satisfaction levels did not reveal any systematic differences compared to the completed surveys (Dillman, 2000).

Of those filling out the survey, $95 \%$ considered themselves either members or frequent guests attending more than twice a month, $90 \%$ of respondents attended at least three times a month. More than $70 \%$ percent of respondents had been customers for more than one year. Looking at education, $72 \%$ had completed some amount of education beyond high school, $14 \%$ had completed a four-year college degree or more. Only $2.4 \%$ reported their status as unemployed. There was an even split on dual income families, with $50 \%$ reporting that both husband and wife worked outside the home. Earnings exceeded national averages: 50\% earned more than $\$ 50 \mathrm{~K}$ per year, $20 \%$ reported incomes greater than $\$ 100 \mathrm{~K}$ per year. With regard to family demographics, $60 \%$ reported one or more children under the age of 18 living at home. 
Out of an initial forty-one items, seven were deleted in the measure purification process. The deleted items were reasonably similar in content to items retained (Hair et al., 1998). The pedigrees of these measures are also listed in Table 1. The coefficient alpha of the final set of scale items ranged from .748 for trust to .937 for future intention indicating acceptable levels of reliability (Nunnally, 1978). Self-administrated questionnaires were used in all cases. The items used to measure the constructs are shown in Table 1. All factor loadings exhibited values in excess of .5, with most over .8 (Dillman, 2000; Hair et al., 1998). In common with past research results (Garbarino and Johnson, 1999; Morgan and Hunt, 1994), trust was the worst performing construct.

INSERT TABLE 1 HERE

\section{Analysis}

Table 2 shows the goodness of fit statistics for the exogenous and endogenous constructs for the models of interest (Models 2, 3, and 4). All but one of these constructs demonstrated a chi-square $\left(\chi^{2}\right)$ that was statistically significant at the .05 level; however, the lack of fit shown by the $\chi^{2}$ statistic is not uncommon in structural equation modeling when a large sample size is obtained (Bagozzi and Yi, 1988). The more commonly used model fit diagnostics (GFI, AGFI, RMSEA. RMR, SRMR, NFI, and CFI) demonstrate that the parameter estimates all fell within acceptable parameters (Bagozzi and Yi, 1988; Byrne, 1998; Williams and Holahan, 1994).

\section{-INSERT TABLE 2 HERE}

Table 3 provides measures of discriminant validity and reliability with inter-trait correlations. All correlations were generally lower than reliability estimates and show acceptable performance. Given the performance of the items, their face validity, content validity, the multiple-step process in scale development and refinement, as well as the documented pedigree of the scale items, the scale items were concluded to have demonstrated 
acceptable levels of reliability, as well as convergent and discriminant validity (Hair et al., 1998; Churchill, 1995; Huck, 2004).

-INSERT TABLE 3 HERE-

Table 4 shows the outcomes for each model. Table 4 shows that Model 1 provides satisfactory fit; in addition, the resulting fit and performance are similar to the results obtained in other studies involving trust, commitment, and future intention (Garbarino and Johnson, 1999; Morgan and Hunt, 1994; Gruen et al., 2000; Sirdeshmukh et al., 2002).

Comparing models to each other following the technique of both Morgan and Hunt (1994) and Garbarino and Johnson (1999) identifies the best model based upon: (1) overall fit statistics, (2) percentage of significant paths, and (3) parsimony of the model. Individual path estimates and fit indices demonstrated that all models perform adequately (Figure 1, 2, 3, and 4) (Bagozzi and Yi, 1988; Byrne, 1998). The $\chi^{2}$ global fit indices are significant; however, as previously mentioned, this is not uncommon with large samples (Byrne, 1998). The RMSEA and CFI are among the measures least affected by sample size; all the models returned a CFI $\geq 0.95$. Based upon the criteria of RMSEA $\geq 0.06$ (Hu and Bentler, 1999), only Models 3 and 4 demonstrated good fit. The Global Fit Index (GFI) and Adjusted Global Fit Index (AGFI) values show how well the model fits the population covariance matrix. These indices evaluate the relative amount of variance and covariance that was explained by the model (Byrne, 1998). The AGFI differs from GFI by adjusting for the number of degrees of freedom. Model 1 has a GFI greater than 0.95 but only Model 3 has both the AGFI and GFI greater than the 0.95 recommended by many researchers (c.f., Schumacker and Lomax, 2004). The information theory based indices provide indices that correct for the problem of model overparameterization and lack of parsimony, with lower indices indicating better fit. The Akaike Information Criterion (AIC) and Consistent AIC (CAIC) for Model 3 show 40\% and 25\% improvements respectively relative to the next best model (Model 1). 
Model 2 introduced the newly-developed construct connection in place of trust. The introduction of connection did not appreciably change the model performance, indeed on all indices there was a slight decrease in performance. Turning to AIC and CAIC, the common indices for nested model testing we see that Model 2 performs slightly worse than Model 1 (Bagozzi and Yi, 1988; Byrne, 1998). This suggests that trust in general performs superiorly to connection in concert with commitment, and that connection may share some identity with commitment. Hypotheses 1 is weakly supported

From a competing model perspective based upon Model 1 the classic configuration of trust, commitment and future intention, the results show that Model 3 performed superiorly on all measures. Most importantly, we find that the CAIC and SRMR of Model 3 demonstrated a significant improvement over the both the validation model and Model 1. CAIC and SRMR is an appropriate index for comparing non-nested models (Bagozzi and Yi, 1988; Byrne, 1998). These results confirm Hypothesis 2.

Model 3 introduces connection in the place of trust to provide a model of trust, connection and future intention (Figure 4). The introduction of connection in the place of commitment improved the model performance on all indices. Turning to AIC and CAIC- the common indices for nested model testing-we see that Model 3 performs superior to both Model 1 and Model 2 (Bagozzi and Yi, 1988; Byrne, 1998). This suggests that connection captures some element of commitment while at the same time capturing additional previous error to generate superior performance concert with trust. Hypothesis 2 is strongly supported. Model 4 introduces connection into the classic model of trust and commitment. On all measures Model 4 performs well by suggested standards, yet poorly in comparison with Model 1. Hypothesis 3 is rejected. 
Overall the results demonstrate that Model 3 performs superiorly to the other models. All the models provide an improvement in all indices over the baseline Validation Model. However, only Model 3 exceeded the expectations for CFI, RMSEA, GFI, and AGFI while also demonstrating sizeable improvements to AIC and CAIC. Additionally, for the traditional Morgan and Hunt model (Model 1), trust's influence on future intention was not significant, a finding that appears elsewhere (Garbarino and Johnson, 1999; Morgan and Hunt, 1994). The improvement in model fits provides evidence that connection partially mediates the effect of trust on future intention. Furthermore, trust and connection performed superiorly to models that included commitment. Based upon this evidence and the previously discussed model fit outcomes, the overall results shown in Table 4 provide evidence that Model 3 provides the best overall fit and connection provides valuable explanatory power for predicting outcomes of customer relationship models of component satisfaction and trust.

\section{Discussion}

This investigation tested how the presence of sense of connection influenced models of trust, commitment, and future intention. The results show that connection improves prediction of future intention when modeled with trust and in the place of commitment. These results provide some evidence that connection explains some aspects of future intention not explained by trust and commitment. Based upon this evidence, connection appears to influence the relational orientation of customers.

Two primary findings characterize this research. First is the presentation of empirical evidence for connection as a missing dimension of co-creation. The importance of the connection construct lies in: 1) its contribution, along with trust and commitment, to measuring the degree of co-creation in a relational exchange, and 2) its vindication of the cocreation process of S-D Logic as an important factor in the exchange process. 
The findings are generally consistent with previous studies dealing with component satisfaction, trust, commitment, and future intention. However, this investigation goes beyond those studies to suggest that connection: 1) appears to have qualities similar to those of trust and commitment; 2) connection is a real construct from the perspective of customers and staff in a highly relational organization; 3) connection, trust and commitment are effective predictors of future intention in a relational setting; 4) that connection, trust, and commitment may comprise dimensions of a higher order co-creation construct; and 5) the findings supporting a multi-dimensional co-creation construct are consistent with extant literature.

In line with past research findings, the results confirmed the positive and significant impact of trust on commitment and future intention. The investigation shows that connection is potentially a part of a multi-dimensional co-creation construct that helps explain the mechanism between increased choice, satisfaction, and future intention. However, inclusion of the connection construct appeared to weaken the influence of commitment. This finding suggests that although connection is distinct from commitment and trust, it is related.

The results show that trust, commitment, and connection have significant influence on future intention. Morgan and Hunt (1994) called commitment "relational commitment" and stated that this commitment was embodied in a single construct. This investigation confirms the suggestion (Jaworski and Kohli, 2006) that connection may infer, along with trust and commitment, a single albeit multi-dimensional, comprehensible, and stable construct.

The evaluation of rival models demonstrated that connection along with trust or commitment performs similarly to trust and commitment with respect to future intention. In comparison to the validation model the results suggest connection may provide a mechanism not only to measure future intention, but also to impact future intention. Additionally, this mechanism appears to transcend component level satisfaction or increased choice. 


\section{Implications for Theory}

S-D Logic's emphasis on exchange as essentially related to service outcomes-even when the outcomes of these services involve physical goods_-suggests that theoretical relationships captured by service quality research should constitute at least one pillar for the development of a comprehensive theory of exchange. Connection captures one dimension of the interaction between the customer and the organization in the value-creation exchange process. In the context of this study's results, numerous studies have attempted to examine the impact of satisfaction on future intention (Prahalad and Ramaswamy, 2004; Zeithaml et al., 1996; Cronin and Taylor, 1994; Parasuraman et al., 1991; Parasuraman et al., 1994b). Other studies have attempted to evaluate satisfaction, relationship, trust, and commitment (Garbarino and Johnson, 1999; Morgan and Hunt, 1994). These studies have attempted to relate service quality, overall satisfaction, and behavioral intention with trust and commitment without modeling relationship as a construct. At the same time, recent conceptual literature suggests that co-creation may be a more efficient indicator of the customer's perception of value (Prahalad and Ramaswamy, 2004; Payne et al., 2008; Prahalad, 2004; Jaworski and Kohli, 2006; Liang and Wang, 2008; Ballentyne and Varey, 2006).

This study builds upon S-D Logic to update the variables trust and commitment in a service organization setting. The results integrate and expand these works to explain how perceptions of connection are influenced by measures of satisfaction, and how this perception influences future intention. Furthermore, our study shows that connection is an effective construct that is potentially less intractable than measurement of trust and commitment.

This investigation has demonstrated that connection combines well with trust and commitment as a valid precursor to future intention. The investigation has also shown that connection performs similarly to trust and commitment. This is a significant finding because the current literature presents conflicting results on the model structure that relates 
satisfaction, trust, commitment, and future intention. Tax et al. (1998) found that dissatisfaction quickly erodes trust, but commitment continues for a longer time. They posited that the effect of dissatisfaction is diminished by expectations of future benefits resulting from the history of past encounters (Tax et al., 1998). This investigation found that the degree of connection diminishes the impact of dissatisfaction. This finding potentially explains why some researchers have shown that performance at the attribute level has influenced repurchase intentions while other researchers have questioned whether repurchase intentions are influenced by overall satisfaction (Mittal et al., 1998).

At a practical level, these findings eliminate the need to use two models to model the different behavioral outcomes of customers. Connectedness appears to explain the different influences of trust and commitment on exchange outcomes. Additionally, connectedness captures the relational orientation of customers on a spectrum - a much more realistic measure than the relational-transactional dichotomy that has been used in past research (Garbarino and Johnson, 1999; Morgan and Hunt, 1994).

\section{Implications for Managers}

Many businesses are well aware that life-long customers are not necessarily profitable customers (Reinartz et al., 2000). Correctly targeting customers based upon their required level of involvement in the co-creation process is critical to increase business efficiency through more efficient exchange interactions. By means of assessing and conceptualizing customer connection, managers can re-evaluate business offerings so as not to under- nor over-serve customers. Additionally, recognizing that the co-creation process evolves over time enables managers to engage dynamically with customers rather than treat them as static, passive entities who, once captured by the firm, do not require additional involvement on the part of firm decision-makers. 
Despite the potential benefits of its implementation, one concern with the connection construct is its very richness. Day \& Montgomery (1999, p. 12) have pointed out that, “...The continuing challenge for the academic will be to find simpler yet robust and defensible models for capturing important market phenomena.” This research has provided empirical support that can guide practitioners' actions with a construct that is conceptually concise and easy to measure. The investigation demonstrated that efforts to involve the customer as the co-creator have a positive influence on future intention. Picking up on the recommendation of prior research, this work identified and empirically tested the social dimensions of satisfaction and supports a re-examination of customer relationship management (Fournier and Mick, 1999; Fournier et al., 1998). The investigation found through structural models that a co-creation construct likely influences future intention and is potentially composed of elements of trust, commitment, and connection. This work represents one of the first studies of a major relational customer group aimed at investigating how relationship, through cocreation, affects behavioral intention. Service organization managers and non-profit philanthropic organizations have the ability to take advantage of this insight.

Within the target organization, leaders are instituting programs to manage co-creation. Our target organization is a world-class organization and one of the fastest growing churches in America (Easum, 2005, 2006). Instead of expanding their current facility, they are offering more service times and are offering services in additional locations in order to provide a smaller, more intimate atmosphere and more co-creation opportunity. Additionally, they are increasing their emphasis on small group service experiences as a subset to the overall service experience. Similar approaches are available to other organizations. Instead of large central libraries and large mega-markets, neighborhood libraries and markets could provide a return to the hometown feel, thereby leveraging the consumer's sense of social resources, greater 
satisfaction with dyadic elements of consumption experience and an improved return on investment (Arnould et al., 2006).

This research shows that consumers can perceive a connection, or active co-creation, with both senior leadership and frontline personnel of an organization as well as with fellow customers. This finding provides a new incentive for firms to reassert the role of connection, through co-creation, between fellow customers and staff. For the family physician, a few extra seconds spent by the receptionist, the nurses, or the physician may increase the connectedness with the patrons and boost overall satisfaction. Similarly, programs that encourage clientele to get to know one another, and highlight each other's contributions to the organization, may also enhance the co-creation dynamic. Non-profit organizations like museums might consider inviting highly relational customers (those who give money and volunteer time) to social mixers that emphasize connection with senior staff, service staff, and fellow patrons.

\section{Limitations and Future Directions}

This study suffers from several limitations. Most importantly, we develop and test our construct in the confines of a single organization. In order to gauge the generalizability of our findings, subsequent studies on diverse samples are required. However, the survey and model could easily be adapted to physician's networks, legal firms, accounting firms, community theatres, museums, and a number of other highly relational service activities.

The religious context of this investigation potentially limits the generalizability of the findings. However, the degree of similarity of our findings with that of Garbarino and Johnson's (1999) theatre study justifies some optimism about the generalizability of our conclusions. Further, this approach is supportive of inductive theory generation in which research takes place in a sample substantively rich in the phenomena under investigation 
(Charmaz, 2006; Glaser, 1992). Taken together, these works suggest the possibility of a general psychometric phenomenon that underlies how customers relate to their servicing organizations. Additionally, trust, commitment, and connection represent constructs with some degree of emotional involvement; the influence of rational factors on commitment and relationship involvement is an area of research worthy of further work. Extension of these findings also requires evaluation in alternative populations.

\section{Conclusions}

This investigation sheds light on conflicting results of past research studying component satisfaction and future intention. The empirical findings of this study provide evidence that connection is a step toward filling this gap. The research provides valuable insights into the sparse field of empirical studies examining the relational aspects of co-creation with respect to marketing concepts. The findings support the contention that the co-creation construct offers additional explanatory power when considering models of relationship marketing involving trust, commitment, satisfaction, and behavioral intention. The empirical evidence supports the contention that consumer relationship, as operationalized through co-creation, should influence future intention (Garbarino and Johnson, 1999; Fournier and Mick, 1999; Liang and Wang, 2008; Mick and Fournier, 2000). 
References

Anderson E.W., Fornell C., and Lehmann, D.R. (1994) Customer satisfaction, market share, and profitability: Findings from Sweden, Journal of Marketing, 58(3), pp. 53-66.

Arnould, E.J., Price, L.L., and Malshe, A. (2006) Toward a culture of resource-based theory of the customer. In Lusch, R.F. and Vargo, S.L. (ed.), The Service Dominant Logic of Marketing, Armonk, New York: M.E. Sharpe, pp. 91-104.

Bagozzi, R.P. and Yi, Y. (1988) On the evaluation of structural equation models, Journal of the Academy of Marketing Science, 16(Spring), pp. 79-94.

Ballantyne, D. and Varey R.J. (2006) Creating value-in-use through marketing interaction: The exchange logic of relating, communicating and knowing, Marketing Theory, 6(3), pp. 335-48.

Byrne, B.M. (1998) Structural Equation Modeling: With LISREL, PRELIS, and SIMPLIS, Mahwah, New Jersey: Lawrence Erlbaum Associate.

Charmaz, K. (2006) Constructing grounded theory: A practical guide through qualitative analysis, Thousand Oaks, California: Sage Publications, Inc.

Chen, C. and Watanabe, C. (2007) Competitiveness through co-evolution between innovation and institutional systems - new dimensions of competitiveness in a service-oriented economy, Journal of Services Research, 7(2), pp. 27-55.

Churchill, A.G. (1995) Marketing research: Methodological Foundations, 6th ed. Hindsdale, Illinois: The Dryden Press.

Cronin, J.J. and Taylor, S.A. (1992) Measuring service quality: A re-examination and extension, Journal of Marketing, 56(3), pp. 55-68.

Cronin, J.J. and Taylor, S.A. (1994) SERVPERF versus SERVQUAL; reconciling performance-based and perceptions-minus-expectations measurement of service quality, Journal of Marketing, 58(1), pp. 125-131.

Czepiel, J.A. (1990) Service encounters and service relationships: Implications for research, Journal of Business Research, 20(1), pp. 13-21.

Day, G. and Montgomery, D. (1999) Charting new directions for marketing, Journal of Marketing, 63(Special Issue), pp. 3-13.

Dillman, D.A. (2000) Mall and Internet Surveys, 2nd ed., New York: John Wiley and Sons.

Easum, B. (2006) 100 fastest growing churches 2006, Outreach Magazine, 5(July/August).

Easum, B. (2005) The exponential church, Outreach Magazine, 4(May/June).

Eisenhardt, K.M. (1991) Better stories and better constructs: The case for rigor and comparative logic, Academy of Management Review, 16(3), pp. 620-7.

Eisenhardt, K.M. (1989) Building theories from case study research, Academy of Management Review, 14(4), pp. 532-50.

Fiocca, R. (1982) Account portfolio analysis for strategy development, Industrial Marketing Management, 11(1), pp. 53-62.

Fornell, C. (1992) A national customer satisfaction barometer: The Swedish experience, Journal of Marketing, 56(1), pp. 6-21.

Fournier, S. (2002) Secrets of customer relationship management: It's all about how you make them feel, Journal of Services Marketing, 16(7), pp. 700-703.

Fournier, S., Dobscha, S., and Mick, D.G. (1998) Preventing the premature death of relationship marketing, Harvard Business Review, 76(1), pp. 42-44.

Fournier. S. and Mick, D.G. (1999) Rediscovering satisfaction, Journal of Marketing, 63(4), pp. 5-23.

Garbarino, E., and Johnson, M.S. (1999) The different roles of satisfaction, trust and commitment in customer relationships, Journal of Marketing, 63(2), pp. 70-87. 
Geyskens, I., Steenkamp, J.B.E.M., Scheer, L.K., and Kumar, N. (1996) The effects of trust and interdependence on relationship commitment: A trans-Atlantic study, International Journal of Research in Marketing, 13(4), pp. 303-317.

Glaser, B.G. (1992) Basics of Grounded Theory Analysis, Mill Valley, California: Sociology Press.

Gruen, T.W., Summers, J.O., Acito, F. (2000) Relationship marketing activities, commitment, and membership behaviors in professional associations, Journal of Marketing, 64(3), pp. 34-49.

Gustafsson, A., Johnson, M.D., Roos, I. (2005) The effects of customer satisfaction, relationship commitment dimensions, and triggers on customer retention, Journal of Marketing, 69(4), pp. 210-8.

Hair, J.R., Anderson, R.E., Tatham, R.L., and Black, W.C. (1998) Multivariate Data Analysis, 5th ed., New York: Prentice Hall.

Hu, L. and Bentler P.M. (1999) Cutoff criteria for fit indexes in covariance structure analysis: Conventional criteria versus new alternatives, Structural Equation Modeling, 6, pp. 155.

Huck, S.W. (2004) Reading Statistics and Research, 4th ed. Boston: Pearson.

Jaworski, B. and Kohli, A.K. (2006) Co-creating the voice of the customer. In Lusch, R.F. and Vargo, S.L. (ed.), The Service Dominant Logic of Marketing, Armonk, New York: M.E. Sharpe, pp. 109-117.

Johnson, M.D. and Selnes, F. (2004) Customer portfolio management: Toward a dynamic theory of exchange relationships, Journal of Marketing, 68(April), pp. 1-17.

Kohli, A.K. and Jaworski, B.J. (1990). Market orientation: The construct, research propositions, and managerial implications, Journal of Marketing, 54(2), pp. 1-18.

Kohli, A.K., Jaworski, B.J., and Kumar, A. (1993) MARKOR: A measure of market orientation, Journal of Marketing Research, 30(4), pp. 467-77.

Landrum, H. and Prybutok, V.R. (2004) A service quality and success model for the information service industry, European Journal of Operational Research, 156(3), pp. 628-642.

Levitt, T. (1960) Marketing myopia, Harvard Business Review, 38(4), pp. 45-56.

Liang, C. and Wang, W. (2008) Do loyal and more involved customers reciprocate retailer's relationship efforts? Journal of Services Research, 8(1), pp. 63-90.

Lusch, R.F. and Vargo, S.L. (2006) Service dominant logic as a foundation for a general theory. In Lusch, R.F. and Vargo, S.L. (ed.), The Service Dominant Logic of Marketing, Armonk, New York: M.E. Sharpe, pp. 406-20.

Mick, D.G. and Fournier, S. (2000) I can't get no satisfaction (without really knowing customers' experiences). In: Proceedings of the American Marketing Association, 11, 81.

Mittal, V., Ross, W.T. and Baldasare, P.M. (1998) The asymmetric impact of negative and positive attribute-level performance on overall satisfaction and repurchase intentions, Journal of Marketing, 62(1), pp. 33-47.

Moliner, M.A., Sánchez, J., and Rodríguez, R.M. (2007) Perceived relationship quality and post -purchase perceived value, European Journal of Marketing, 41(11/12), pp. 13921422.

Moorman, C., Zaltman, G., and Deshpandé, R. (1992) Relationships between providers and users of market research: The dynamics of trust within and between organizations, Journal of Marketing Research, 29(3), pp. 314-328.

Morgan, R.M. and Hunt, S.D. (1994) The commitment-trust theory of relationship marketing, Journal of Marketing, 58(3), pp. 20-38. 
Narver, J.C. and Slater, S.F. (1990) The effect of market orientation on business profitability, Journal of Marketing, 54(4), pp. 20-35.

Nunnally, J.C. (1978) Psychometric Theory, New York: McGraw-Hill.

Oliver, R.L. (2006) Co-production and co-participants in the satisfaction process: Mutually satisfying consumption. In Lusch, R.F. and Vargo, S.L. (ed.), The Service Dominant Logic of Marketing, Armonk, New York: M.E. Sharpe, pp. 118-127.

Palmatier, R.W., Dant, R.P., Grewal, D. and Evans, K.R. (2006) Factors influencing the effectiveness of relationship marketing: A meta-analysis, Journal of Marketing, 70(4), pp. 136-53.

Parasuraman, A., Berry, L.L. and Zeithaml, V.A. (1991) Refinement and reassessment of the SERVQUAL scale, Journal of Retailing, 67(4), pp. 420-450.

Parasuraman, A., Zeithaml, V,A., and Berry, L.L. (1994a) Alternative scales for measuring service quality: A comparative assessment based on psychometric and diagnostic criteria, Journal of Retailing, 70(3), pp. 201-230.

Parasuraman, A., Zeithaml, V.A., and Berry, L.L. (1994b) Reassessment of expectations as a comparison standard in measuring service quality: Implications for further research, Journal of Marketing, 58(1), pp. 111-24.

Payne, A.F., Storbacka, K., and Frow, P. (2008) Managing the co-creation of value, Journal of the Academy of Marketing Science, 36(1), 83-96.

Prahalad, C.K. and Ramaswamy, V. (2004) Co-creation experiences: The next practice in value creation, Journal of Interactive Marketing, 18(3), pp. 5-14.

Prahalad, C.K. (2004) The co-creation of value, Journal of Marketing, 68(1), pp. 22-3.

Rangan, V.K., Menezes, M.A.J., and Meier, E.P. (1992) Channel selection for new industrial products: A framework, method, and application, Journal of Marketing, 56(3), pp. 6982.

Reinartz, W.J. and Kumar, V. (2000) On the profitability of long-life customers in a noncontractual setting: An empirical investigation and implications for marketing, Journal of Marketing, 64(4), pp. 17-35.

Schumacker, R.E. and Lomax, R.G. (2004) A Beginner's Guide to Structural Equation Modeling, Mahwah, New Jersey: Lawrence Erlbaum.

Seiders, K., Voss, G.B., Grewal, D. and Godfrey, A.L. (2005) Do satisfied customers buy more? Examining moderating influences in a retailing context, Journal of Marketing, 69(4), pp. 26-43.

Sirdeshmukh, D., Singh, J. and Sabol, B. (2002) Consumer trust, value, and loyalty in relational exchanges, Journal of Marketing, 66(1), pp. 15-37.

Szymanski, D.M., Henard, D.H. (2001) Customer satisfaction: A meta-analysis of the empirical evidence, Journal of the Academy of Marketing Science, 29(1), pp. 16-35.

Tax, S.S. and Brown, S.W. (1998) Recovering and learning from service failure, Sloan Management Review, 40(1), pp. 75-88.

Tax, S.S., Brown, S.W., Chandrashekaran, M. (1998) Customer evaluations of service complaint experiences: Implications for relationship marketing, Journal of Marketing, 62(2), pp. 60-76.

Ulaga, W. and Eggert, A. (2006) Relationship value and relationship quality, European Journal of Marketing, 40(3/4), pp. 311-27.

Vargo, S.L. and Lusch, R.F. (2004) Evolving to a new dominant logic for marketing, Journal of Marketing, 68(1), pp. 1-17.

Verhoef, P.C. (2003), Understanding the effect of customer relationship management efforts on customer retention and customer share development, Journal of Marketing, 67(4), pp. 30-45. 
Westbrook, R.A. (1981) Sources of consumer satisfaction with retail outlets, Journal of Retailing, 57(3), pp. 68-85.

Wetzels, M., de Ruyter, K. and Van Birgelen, M. (1998) Marketing service relationships: the role of commitment, Journal of Business \& Industrial Marketing, 13(4/5), pp. 406-23.

Williams, L.J. and Holahan, P.J. (1994) Parsimony-based fit indices for multiple-indicator models: Do they work? Structural Equation Modeling, 1(2), pp. 161-89.

Zeithaml, V.A, Berry, L.L. and Parasuraman A. (1996) The behavioral consequences of service quality, Journal of Marketing, 60(20), pp. 31-46. 


\section{FIGURES AND TABLES}

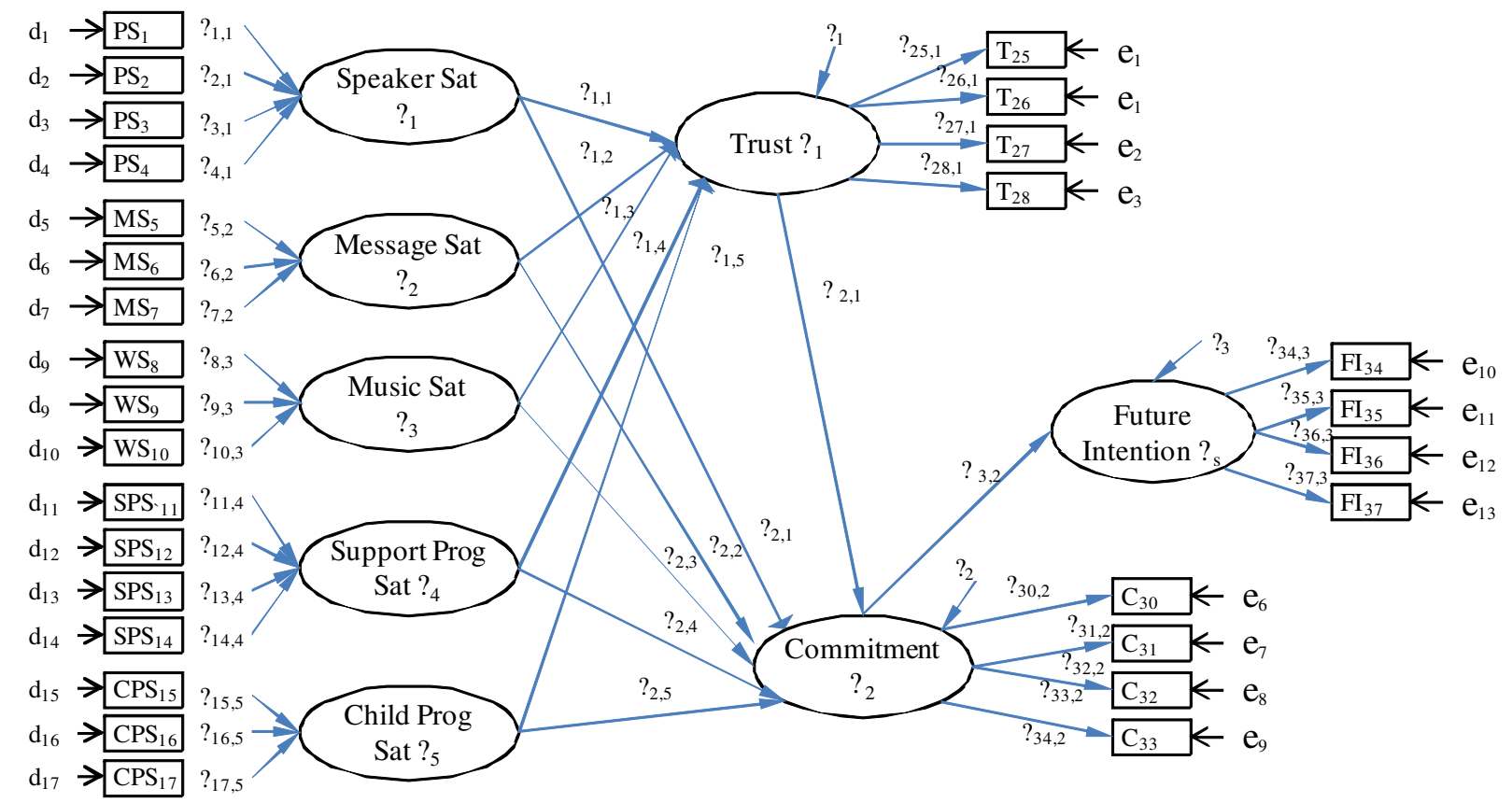

Figure 1. Validation model (validation of sample and relational structure).

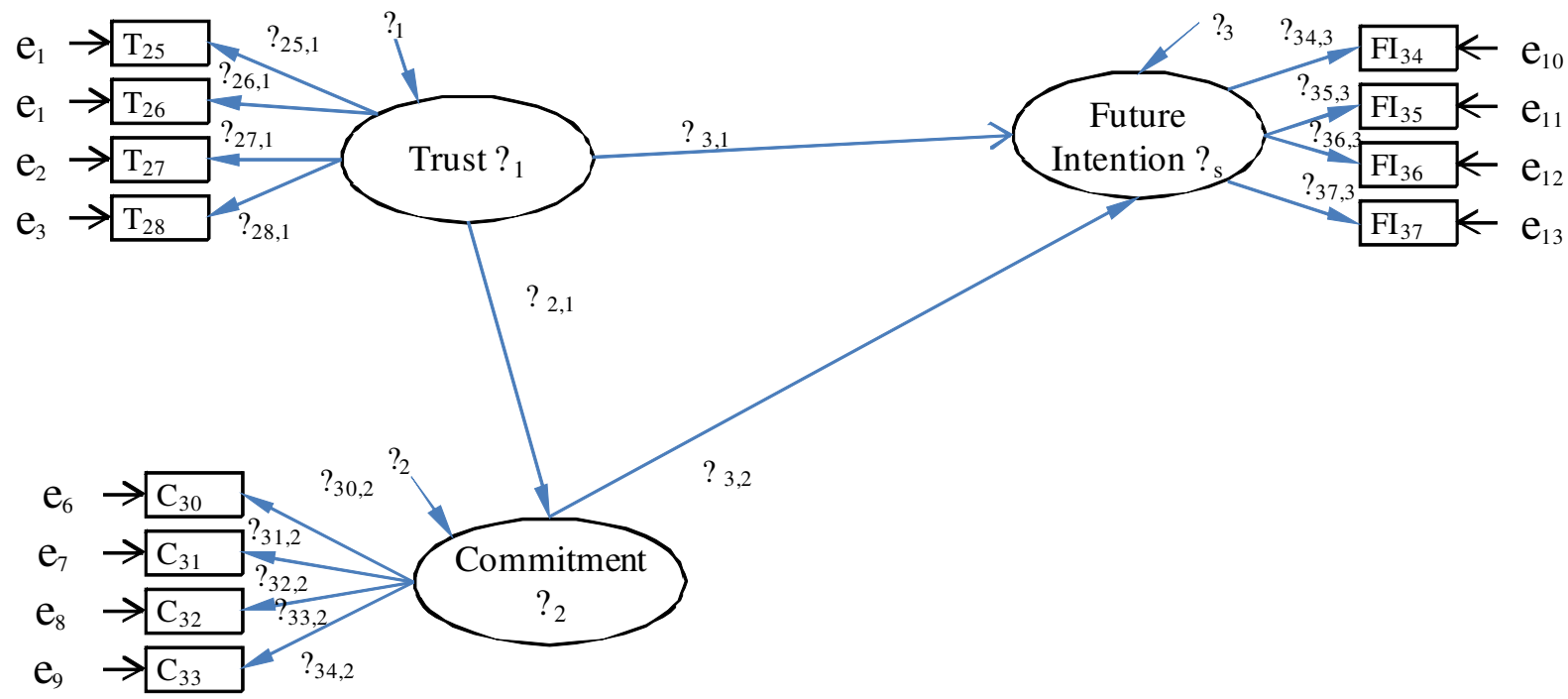

Figure 2. Model 1-- Trust, commitment, and future intention. 


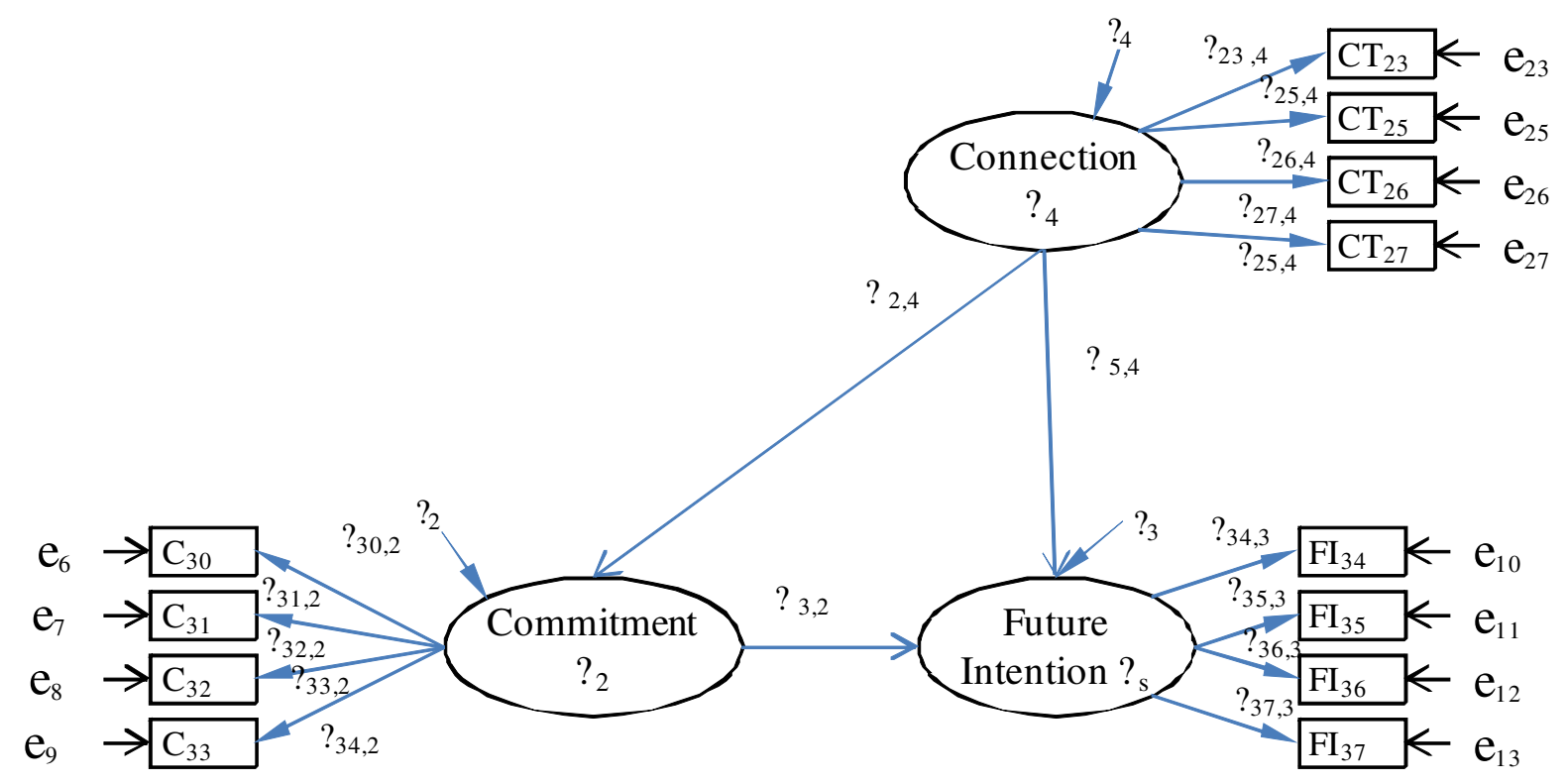

Figure 3. Model 2--Commitment, connection, and future intention.

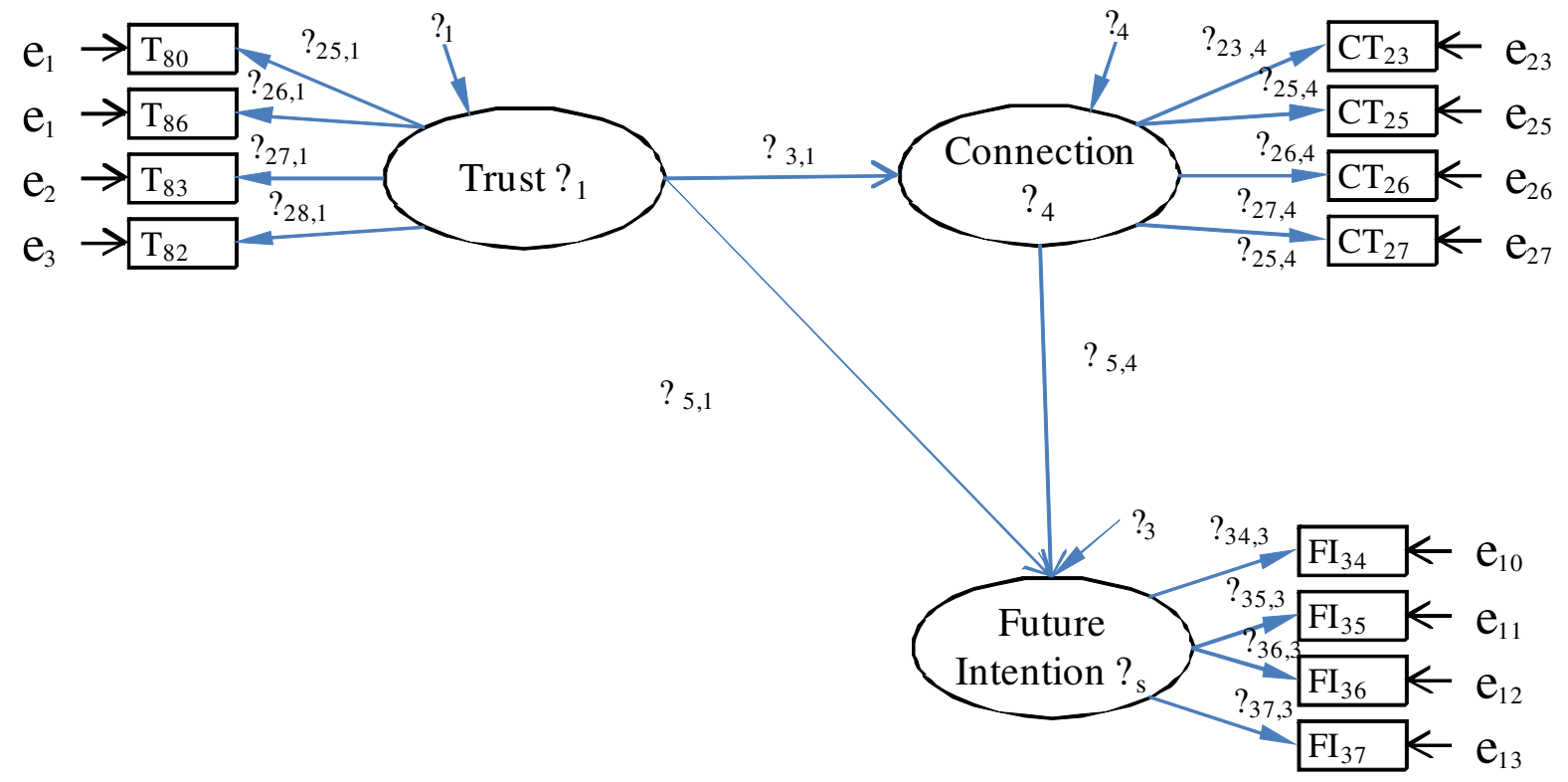

Figure 4. Model 3--Trust, connection, and future intention. 


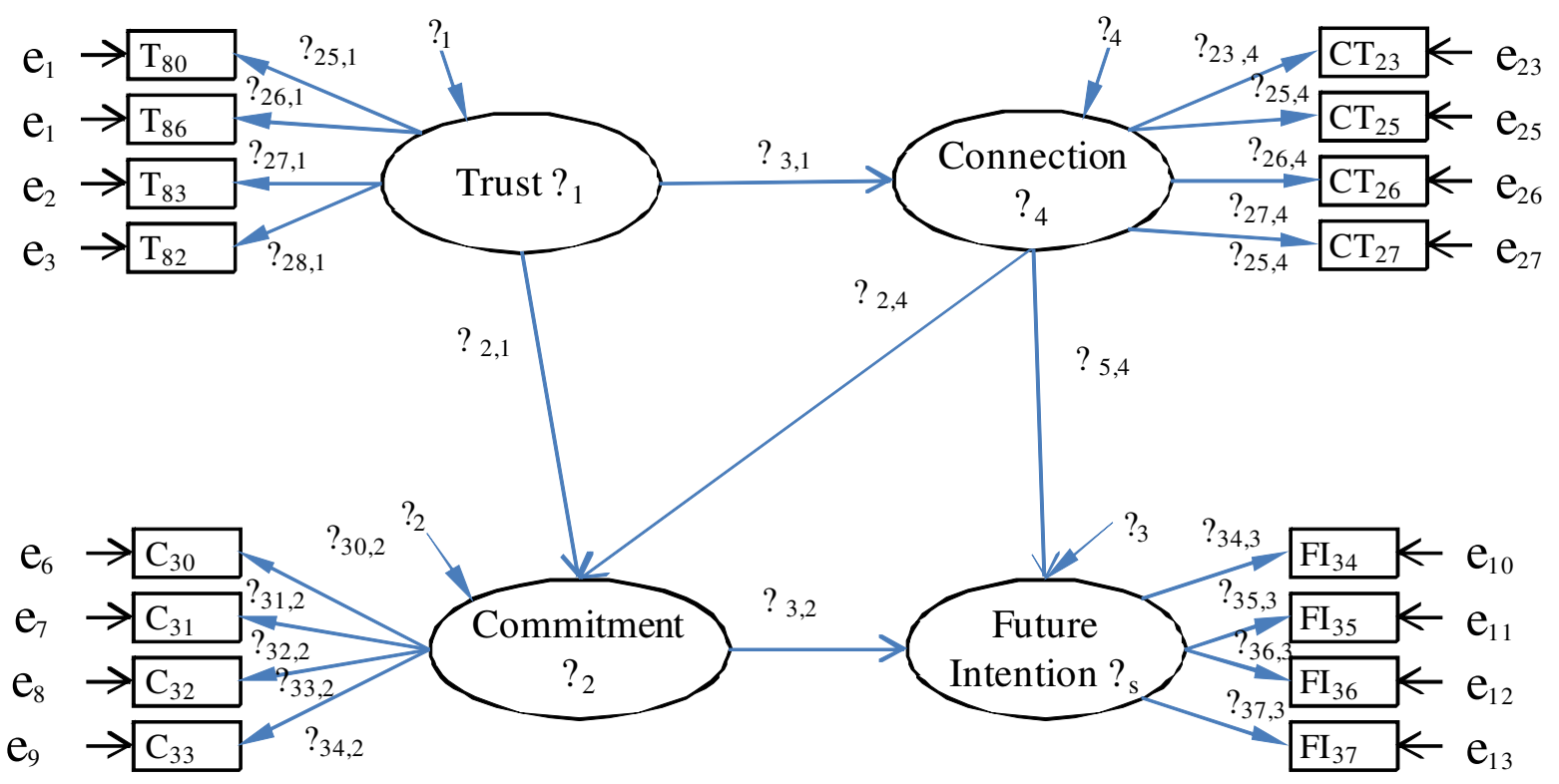

Figure 5. Model 4--Trust, commitment, connection, and future intention. 
Table 1. Measurement Model and Confirmatory Factor Analysis

\begin{tabular}{|c|c|c|c|}
\hline \multirow[t]{2}{*}{ Exogenous Constructs } & \multicolumn{2}{|c|}{ Item-Construct Loading } & \multirow[t]{2}{*}{ Cronbach's Alpha } \\
\hline & Standardized & C.R. & \\
\hline Trust (F:4 I:6) *1,2 & & & 0.748 \\
\hline 1. I worry that the Sunday service at this church will not be good (Q79) & 0.808 & 12.503 & \\
\hline 2. This church cannot be trusted at times (Q83) & 0.837 & 11.893 & \\
\hline 3. I am concerned that the Sunday service will not be worth my time (Q85) & 1.00 & N/A & \\
\hline 4. I am concerned that my involvement with this church will not be worth my time Q86 & 0.916 & 13.080 & \\
\hline Commitment (F:4 I:5) *1,2 & & & 0.913 \\
\hline 1. I intend to go to this church as long as I live here (Q92) & 0.954 & 24.789 & \\
\hline 3. I want my friends to attend this church (Q96) & 0.853 & 22.842 & \\
\hline 4. I am very committed to this church (Q97) & 1.000 & N/A & \\
\hline \multicolumn{4}{|l|}{ Exogenous Constructs } \\
\hline & Standardized & C.R. & \\
\hline Connection (F:4, I:5) & & & 0.854 \\
\hline 1. I feel a sense of connection with a pastor or staff member (Q23) & 0.892 & 19.112 & \\
\hline 2. I feel a sense of connection with the people in the ministry area I serve (Q25) & 0.866 & 18.197 & \\
\hline 3. I feel a sense of connection with the musicians (Q26) & 0.894 & 19.497 & \\
\hline Future Intention (F: $4 \mathrm{I}: 4) * 1,2,3$ & & & 0.937 \\
\hline 1. I plan to increase my involvement in this church (Q104) & 0.904 & 42.602 & \\
\hline 2. I plan to donate more of my time to this church (Q105) & 1.00 & N/A & \\
\hline 3. I plan to donate more of my money to this church (Q106) & 0.787 & 26.629 & \\
\hline 4. I plan to increase my volunteer activities at this church (Q108) & 0.958 & 43.758 & \\
\hline
\end{tabular}

1: Adapted from Garbarino and Johnson (1999)

2: Adapted from Morgan and Hunt (1994)

3: Adapted from Zeithaml, Berry, \& Parasuraman (1996) 
Table 2. Goodness of Fit Statistics for Constructs

\begin{tabular}{|l|c|c|c|c|c|c|c|c|c|c|}
\hline & \multicolumn{10}{|c|}{ Factor Structure Diagnostics } \\
\hline \multicolumn{1}{|c|}{ Constructs } & $\chi 2$ & $p$-value & Df & GFI & AGFI & RMSEA & RMR & SRMR & NFI & CFI \\
\hline Exogenous & 115.7 & .000 & 20 & .953 & .916 & .090 & .056 & 0.0385 & .955 & .962 \\
\hline Trust & 2.2 & .524 & 3 & .998 & .994 & .000 & .034 & .0113 & .996 & 1.00 \\
\hline Commitment & 63.027 & .000 & 2 & .952 & .761 & .228 & .040 & .0133 & .963 & .964 \\
\hline Endogenous & 41.52 & .002 & 19 & .983 & .968 & .45 & .069 & .0238 & .988 & .993 \\
\hline Connection & 24.336 & .000 & 2 & .980 & .902 & .138 & .090 & .0268 & .977 & .978 \\
\hline Future Intention & 3.983 & .136 & 2 & .997 & .983 & .041 & .012 & .0057 & .998 & .999 \\
\hline
\end{tabular}


Table 3. Correlation Matrix All Items

\begin{tabular}{|c|c|c|c|c|c|c|c|c|c|c|c|c|c|c|c|c|c|}
\hline OW & AR & 23 & 25 & 26 & 27 & $79 \mathrm{r}$ & $83 r$ & $85 \mathrm{r}$ & $86 \mathrm{r}$ & 92 & 95 & 96 & 97 & 104 & 105 & 106 & 108 \\
\hline EAN & & .801 & .153 & .166 & .338 & .504 & .480 & .625 & .435 & .284 & .312 & .385 & .097 & .727 & .574 & .514 & .511 \\
\hline TDDEV & & .838 & .845 & .809 & .798 & .153 & .269 & .017 & .229 & .270 & .110 & .057 & .223 & .394 & .440 & .438 & .467 \\
\hline & & 89.000 & 89.000 & 89.000 & 89.000 & 89.000 & 89.000 & 89.000 & 89.000 & 89.000 & 89.000 & 89.000 & 89.000 & 89.000 & 89.000 & 89.000 & 89.000 \\
\hline ORR & 23 & .000 & & & & & & & & & & & & & & & \\
\hline ORR & 25 & .593 & .000 & & & & & & & & & & & & & & \\
\hline ORR & 26 & .572 & .494 & .000 & & & & & & & & & & & & & \\
\hline ORR & 27 & .611 & .620 & .674 & .000 & & & & & & & & & & & & \\
\hline ORR & $79 \mathrm{r}$ & .061 & .016 & .088 & .070 & .000 & & & & & & & & & & & \\
\hline ORR & $83 r$ & .118 & .066 & .154 & .070 & .336 & .000 & & & & & & & & & & \\
\hline ORR & $85 \mathrm{r}$ & .125 & .098 & .161 & .123 & .510 & .480 & .000 & & & & & & & & & \\
\hline ORR & $86 r$ & .175 & .134 & .149 & .148 & .388 & .365 & .540 & .000 & & & & & & & & \\
\hline ORR & 92 & .285 & .205 & .298 & .289 & .319 & .433 & .393 & .386 & .000 & & & & & & & \\
\hline ORR & 95 & .371 & .273 & .265 & .295 & .368 & .393 & .423 & .437 & .732 & .000 & & & & & & \\
\hline ORR & 96 & .357 & .263 & .306 & .335 & .375 & .412 & .449 & .405 & .734 & .716 & .000 & & & & & \\
\hline ORR & 97 & .403 & .319 & .319 & .335 & .345 & .327 & .394 & .410 & .659 & .816 & .727 & .000 & & & & \\
\hline ORR & 104 & .226 & .247 & .199 & .255 & .247 & .240 & .275 & .259 & .492 & .414 & .509 & .445 & .000 & & & \\
\hline ORR & 105 & .260 & .277 & .248 & .290 & .238 & .216 & .261 & .247 & .474 & .430 & .508 & .459 & .880 & .000 & & \\
\hline ORR & 106 & .236 & .259 & .221 & .254 & .159 & .233 & .217 & .199 & .413 & .370 & .451 & .401 & .695 & .735 & .000 & \\
\hline ORR & 108 & .255 & .297 & .244 & .304 & .212 & .228 & .240 & .232 & .452 & .431 & .475 & .445 & .820 & .885 & .713 & .000 \\
\hline
\end{tabular}


Table 4. Competing Model Exploratory Analysis

\begin{tabular}{|c|c|c|c|c|c|}
\hline Model & Validation Model & Model 1 & Model 2 & Model 3 & Model 4 \\
\hline $\begin{array}{l}\text { Global } \\
\text { Model Fit } \\
\text { Diagnostics }\end{array}$ & $\begin{array}{l}\text { Rerun of Garbarino and } \\
\text { Johnson (1999) as a } \\
\text { validation model. Effect of } \\
\text { satisfaction on trust, } \\
\text { commitment and future } \\
\text { intention in a relational } \\
\text { sample }^{1} \text {. }\end{array}$ & $\begin{array}{l}\text { Trust, } \\
\text { Commitment, and } \\
\text { Future Intention }\end{array}$ & $\begin{array}{l}\text { Commitment, } \\
\text { Connection, } \\
\text { and Future } \\
\text { Intention }\end{array}$ & $\begin{array}{l}\text { Trust, } \\
\text { Connection } \\
\text { and Future } \\
\text { Intention }\end{array}$ & $\begin{array}{l}\text { Trust, } \\
\text { Commitment, } \\
\text { Connection, } \\
\text { and Future } \\
\text { Intention }\end{array}$ \\
\hline$\chi^{2}$ & 719.799 & 173.6 & 199.5 & 83.4 & 280.6 \\
\hline Df & 353 & 61 & 51 & 51 & 99 \\
\hline p-value & 0.000 & 0.000 & 0.000 & 0.000 & 0.000 \\
\hline GFI & .922 & 0.952 & 0.945 & 0.977 & 0.942 \\
\hline AGFI & .904 & 0.926 & 0.916 & 0.965 & 0.920 \\
\hline RMSEA & .042 & 0.064 & 0.070 & 0.033 & 0.056 \\
\hline RMR & .049 & 0.051 & 0.073 & 0.067 & 0.068 \\
\hline SRMR & .0373 & 0.0333 & 0.0347 & 0.0288 & 0.0345 \\
\hline NFI & .957 & 0.966 & 0.964 & 0.980 & 0.956 \\
\hline CFI & .977 & 0.976 & 0.973 & 0.992 & 0.973 \\
\hline CAIC & 1324.83 & 372.863 & 394.735 & 282.626 & 553.56 \\
\hline AIC & 883.80 & 227.646 & 253.517 & 137.408 & 354.56 \\
\hline Fit Ranking & N/A & 2 & 3 & 1 & 4 \\
\hline $\begin{array}{l}\text { Tests of } \\
\text { Hypothesis }\end{array}$ & & & $\begin{array}{l}\text { H1: weakly } \\
\text { Supported }\end{array}$ & $\begin{array}{l}\mathrm{H} 2: \\
\text { Supported }\end{array}$ & $\begin{array}{l}\text { H3: Weakly } \\
\text { supported }\end{array}$ \\
\hline
\end{tabular}

\footnotetext{
${ }^{1}$ Model performance result similar to that of Garbarino and Johnson 1999
} 


\section{Appendix 1: Sample Validation}

During our initial face-to-face interview, our follow-up interviews, and pilot study we found that the organizational entity (both the formal organization and its customers) relies on co-creation to meet objectives. A large amount of the perceived customer value involves customers' volunteered time and money. Customers co-create music by lending their voice and energy to the worship program. Customers co-create the service atmosphere by acting as greeters, ushers, and prayer partners. Customers cocreate the stage by setting up and taking down chairs, directing traffic, and handing out programs. Volunteer customers, passing appropriate background investigation, cocreate the childcare, and youth services. Recovery, counselling, marriage, and support programs are largely staffed, and managed, by volunteer customers who have either education or life expertise supportive of the work. In conversations with customers, leadership, and staff, we find that customers co-create the spirituality of the offering by sharing experiences. We find that customers co-create service delivery by opening their homes and sharing their stories in well over 100 small groups that meet each week.

The product offered by the church is service-centric, whose it value is in many aspects intangible. This intangibility is consistent with identified shift in the market form product and attributes, towards, service and intangibility (Garbarino and Johnson 1999). This offered value is derived through a co-creation process that involves active and connected customers fully integrated into the production process. The application of service-centric theory, and intangible value generated through co-creation in the current sample is supported by other investigations into non-profit organizations and the role of relationship. 